\title{
The Quality of Listening Skill of the Indonesian EFL Students
}

\author{
Erawati Wiyono Putri \\ IAIN Samarinda, Indonesia \\ email:vierha_iz_me23@yahoo.com \\ Umar Fauzan (Corresponding Author) \\ IAIN Samarinda, Indonesia \\ email: umar.fauzan@iain-samarinda.ac.id

\section{Rostanti Toba} \\ IAIN Samarinda, Indonesia \\ email: anti190481@yahoo.com
}

\begin{abstract}
:
Listening is viewed as a receptive or passive skill that hard to be measured. Nevertheless, listening skill plays a big role in enhancing students' proficiency in English. Therefore, improving students' quality in listening is important. According to Al-Musalli, there are four sub-skills involved in listening: literal level, inferential level, critical level, and creative level. All of these sub-skills can be used as the criteria to view students' mastery level of listening. This research only applies three levels as a benchmark to know students' quality of listening, they are: literal, inferential, and critical. The objective of this research is to know the students' quality in listening skill based on mastery level of listening. The research design is descriptive. The subjects of the study are five students who meet the researcher's criteria. Data collection technique in this research is using test of listening, interview, observation, and documentation. The data is analyzed using the model of Miles \& Huberman. After being collected, the data is verified using triangulation. The result of this research shows that students at the English Education Department
\end{abstract}


in IAIN Samarinda are in the inferential level of mastery listening skill which means their quality in listening can be categorized as good.

Keywords: Listening skill, listening mastery, literal level, inferential level, critical level

\section{Introduction}

A language is a tool that can connect people to the world. Without language, people cannot interact with each other. From many languages that exist in the world, there are some languages that used by many people to build a relationship between different countries, such as China, English, Arabic, and France. One of the languages has a big influence in the global era is English. English is one of the languages used by more than five hundred million people in the world. Many countries make English as their second language (ESL), indeed. On the other hand, Indonesia is not using English as its second language. Nevertheless, this doesn't mean the Indonesian people do not learn English either. English is studied in the formal classes or for specific purposes in Indonesia. One can say that English is learnt as a Foreign Language (EFL) there. The fact that Indonesian is not English native speaker causes learning English is quite complicated for them. At least, the teacher should learn more to have a good qualification in English; to be able to teach English well. The teacher should know what kinds of basic skills as the essential role in teaching English and of course, other important aspects as well.

Maxom (2009) claims that in language courses there are four main skills which needed to be included to make students truly proficient, they are listening, speaking, reading and writing. All of the skills are taught in language teaching and have their own role in the term of communication, such as listening which could help people to get information for a specific purpose. As a matter of fact, listening is the first language mode that children acquire. It provides a foundation for all aspects of language; cognitive developments and it plays a lifelong role in the processes of learning and communication that is essential to productive participation in life (Javed, 2013).

In Indonesian universities, English is a compulsory subject. This according to Indonesian Government Regulation No. 19 Year 2005 in Article 9 about National Education Standard, which establishes that the unit of higher education level curriculum must include of religious education, civic education, Indonesian language, and English. Still, the quality of some skills which mastered by the students in the universities is different. For instance, in term of listening skill, El Meysarah (2015) found that listening ability of state university of Surabaya students is good enough, meanwhile in Riau university, listening ability of Riau university students is still low (Ristanti, et al., 2016). Some efforts have been implemented by the English teachers and lecturers to cope the problems of listening skill of the English learners (Afsharrad \& Nafchi, 2015; Samawiyah \& Saifuddin, 2016; Hanafi, 2016; Cendra, 2017) 
There have been numerous attempts to describe listening comprehension in terms of taxonomies of sub-skills. This approach is based on the notion that these skills underlie the process, and the act of listening consists of the application of various separate skills (Barta, 2010). Besides, every person has a different point of view for every single thing that exists in this world as well as some experts in the term of listening. Al-Musalli (2001) has specified some experts statements into four subskills involved in listening: the literal level, the inferential level, the critical level, and the creative level.

Those four sub-skills above also have a connection to the classes of cognitive (intellectual) behaviours identified by Bloom and others since they were taken from listening comprehension sub-skills; which are as well meant as thinking skills. "knowledge" relate to the literal level of comprehension; "comprehension" and "application" to interpretative level; "analysis" and "evaluation" to the critical level; and "synthesis" to the creative level (Reid, 1981).

In the end, those matters carry us on the contrary of the quality of listening in ESL and EFL students. Their quality of listening may be different based on some factors influencing. For example, at the level of university, ideally, a student of a university has to be able to easily understand what it is being talked by the lecturer or even the native speakers.

To investigate this matter, a research on how is the quality of listening skill of IAIN students especially in the fourth-semester of English Education Department was conducted. This research aimed to view on the quality of students' listening skill based on the indicators of the listening mastery. There are four sub-skills involved in listening skill according to taxonomy of the listening comprehension sub-skills proposed by Al-Musalli (2001): the literal level, the inferential level, critical level, and creative level.

\section{Research Methodology}

The design of this research is descriptive which provides the description of the subjects that are observed. Moreover, this inquiry used two kinds of approach, quantitative and qualitative approaches. The quantitative approach is used in the terms of using a test to know students' score in three different levels of indicators of listening mastery. However, the researcher uses the qualitative approach more than the quantitative approach, in this research. Furthermore, qualitative research is concerned with developing explanations of social phenomena. That is to say, it aims to help us to understand the social world in which we live and why the things are the way they are (Hancock, et al., 2007).

The research subject is five students in the fourth semester of English Education Department of IAIN Samarinda. The data collection techniques are using test, observation, interview, and documentation. The test was conducted in the class. The students were given the answer sheets to write their answers while listening to the conversation presented in front of the class by the researcher. The source of the test question was taken from the lecturer in order to avoid an irrelevant source of the test items. 
Then, the interview was conducted after students did their test. The interview was done as a personal interview. This method requires a person known as the interviewer asking questions generally in a face-to-face contact to the other people. At times, the interviewer might also ask certain questions and the interviewee responds to these, but usually the interviewer initiates the interview and collects the information. This interview is in form of direct, it means the researcher has to collect the information personally from the sources concerned. The researcher has to be on the spot and has to meet people from whom data have to be collected. Moreover, the type of this interview is called as structured interview because the interview involves the use of a set of predetermined questions and of highly standardized techniques of recording. Thus, the interviewer in a structured interview follows a rigid produce laid down, asking questions in a form and order prescribed (Khotari, 2004). Whereas, the observation was conducted in order to observe the students' listening attitude and behavior. It was done by the time the student doing the test. Afterward, documentation was collected from the lecturer after the students did the test.

The data analysis technique of this research is using the model of Miles \& Huberman consisting of three concurrent flows of activity: data reduction, data display, and conclusion drawing/verification (Miles \& Huberman, 1994). Following the model of Miles \& Huberman data analysis flows, the researcher transformed and reduced raw data by sorting and selecting the data from the transcription of interview, observation sheet, and other data sources to be customized into the needs of the inquiry. Then, the data, which have been passed through data reduction, were displayed before finally being taken an action to draw a conclusion or verify.

\section{Findings}

\subsection{Test Result}

The test was held in the second of June 2017. The items of the test are divided into three levels: literal, inferential and critical. Each level has different amount of questions; literal and inferential levels consist of four questions while critical level has sixteen questions. The first part of the question was literal questions. In this part, students were asked to match four conversations with the reason for the call. The A, B, C, and E students were completely correct while D student made one false.

Then, the second part of the question was critical questions. The students were asked to circle the word to answer some questions. The result shows that students have a variety of answer. In the end, out of 5 students only student $\mathrm{E}$ who got the completely correct answer while student B, C got two false and A, D three false.

The last part of the question was inferential questions. The students were asked to check the phrase that best describes the next step somebody has to take according to the conversations. The result shows that only E students answered without any false while $\mathrm{A}, \mathrm{B}$, and $\mathrm{C}$ students were got one false and D two false. Below is the table that shows the students score in each level of question: 
Table 1: The Summary of Students Listening Test

\begin{tabular}{|c|c|c|c|c|c|}
\hline \multirow[b]{2}{*}{ No. } & \multirow[b]{2}{*}{ Student } & \multicolumn{3}{|c|}{ Level } & \multirow[b]{2}{*}{$\begin{array}{l}\text { Total } \\
(24)\end{array}$} \\
\hline & & $\begin{array}{c}\text { Literal } \\
\text { (4 questions) }\end{array}$ & $\begin{array}{c}\text { Inferential } \\
\text { (4 questions) }\end{array}$ & $\begin{array}{c}\text { Critical } \\
\text { (16 questions) }\end{array}$ & \\
\hline 1. & A & 4 & 3 & 13 & 20 \\
\hline 2. & $\mathrm{~B}$ & 4 & 3 & 14 & 21 \\
\hline 3. & $\mathrm{C}$ & 4 & 3 & 14 & 21 \\
\hline 4. & $\mathrm{D}$ & 3 & 2 & 13 & 18 \\
\hline 5. & $\mathrm{E}$ & 4 & 4 & 16 & 24 \\
\hline
\end{tabular}

The table above shows that the dominant level which all students easily passed is in the literal level while the level which student got the many false is in the critical level.

Table 2: Students' Score in Literal Level

\begin{tabular}{|c|c|c|}
\hline No. & Student & Score \\
\hline 1 & A & 100 \\
\hline 2 & B & 100 \\
\hline 3 & C & 100 \\
\hline 4 & D & 75 \\
\hline 5 & E & 100 \\
\hline
\end{tabular}

According to the table above, the students easily passed the literal level and almost all students got a perfect score.

Table 3: Students' Score in Inferential Level

\begin{tabular}{|c|c|c|}
\hline No. & Student & Score \\
\hline 1 & A & 75 \\
\hline 2 & B & 75 \\
\hline 3 & C & 75 \\
\hline 4 & D & 50 \\
\hline 5 & E & 100 \\
\hline
\end{tabular}

The table above shows that only one student got a perfect score while three others got an average score and one student got a poor score.

Table 4: Students' Score in Critical Level

\begin{tabular}{|c|c|c|}
\hline No. & Student & Score \\
\hline 1 & A & 81 \\
\hline 2 & B & 88 \\
\hline 3 & C & 88 \\
\hline 4 & D & 81 \\
\hline 5 & E & 100 \\
\hline
\end{tabular}


Based on the table, only one student got a perfect score while others got good to excellent score.

\subsection{Interview Result}

The data of interview were classified using a coding technique. The interview which conducted by the researcher is a personal interview. Therefore, every student was asked in different time and place. It was also in order to make the interviewees feel relax to answer the questions. The questions in interview consist of eight questions in three different level; three questions for literal, inferential and two questions for critical level. The interview was conducted in order to know the interviewees' perspective on the case of listening skill in a different level.

The first Interview was conducted on Friday, in the seventh of July 2017 at 02:19 PM. Student A was asked several questions. In the literal level, student A was asked about his skill to discriminate some words that sound similar when doing a listening activity in English and he was sure that he could differentiate it. He also gave an example of it.

"Yes, I can differentiate some words that sound similar in the listening section. I also can give the example of it like on the word "I" as "Saya" and "Eyes" as "Mata". (A1)

Continuing to the second question, at the time he was asked about the skill of recognizing basic grammatical structure when listening, he said that sometimes it's a difficult thing to do. At the third question, he was asked about how many percents he could understand the text that played in listening. He said only half of the text which could be understood.

\section{"To be honest, maybe I only understand fifty-fifty". (A2)}

In the fourth question, the inferential level of the question was administered. It was about the understanding of the implied meaning of a passage. Again, the answer is he was able to do that by understanding the sentence as well as the intonation used.

"Usually I understand it by analyzing the sentence used so I can know, oh... this what she was meant or by looking at the intonation used". (A3)

Moving to the fifth question, it was still in inferential level about the technique that the interviewee used in connecting some sentences to gain an answer. He said, there's no special technique used but he could do that. About the sixth question, the answer is still the same, that is, he could recognize the use of cohesive devices and discourse marker. For the two last questions, in the critical level, the interviewee did not respond too much, the thing just said four words: "I think it difficult". (A7)

On Saturday, in the eighth of July 2017, at 04:27 PM, the second interview was held. Yet, it was in the same form of questions as before. The first question was about discriminating word sounds while listening. Student E could do that, but he said that it is sometimes hard to do. Still, it could be the easy thing as well. 
"For me sometimes it can be difficult or easy based on the dialogues if it was presented by Indonesian, it may be easy but if it was a native speaker that might hard for me." (E1)

For the second question, he answered that he only could recognize the basic grammatical structure of the text unless the text is already familiar with him. He also admitted that he did not really care about the structure but more about into the speaker of the text.

"Depend on the text if it's familiar for us, we can easily recognize the form of the text". "I don't really pay attention to the structure of the text while listening. I just focus on what is meant and wanted by the speakers." (E2)

For the third question, the interviewee said that he could understand the vocabulary used but not all of them. He thought that we just need to take some important points to understand all the text.

"Not all that I can understand, but in understanding English dialogue we don't have to understand all because it will take a long time. Just take some points to know the final point." (E3)

Moreover, about the inferential level of the question in the fourth question, it was the understanding of implied message in the listening activity. At the interview, student E explained how he could find the implied message by paying attention to both of the passage and the questions while doing a listening activity.

"I pay attention to listen to the passage and the questions given so in the final I can find the implied message of the text". (E4)

The answer of the interviewee given quickly, which had just been administered, for the fifth question about the technique used to answering listening task proven that student E was able to connect one sentence to another sentence to gain the right answer.

Then, by figuring out to the interviewee's answer in question six, the researcher knew that student $\mathrm{E}$ could recognize the use of discourse markers and cohesive devices from the spoken discourse. However, in the critical level of the question, the interviewee didn't say much but only the difficult words. Still, they sometime could answer the critical level of the question if they have prior knowledge about it.

\section{"Judge something that you hear is not easy if we don't understand} the way to do that". (E7)

The third interview was accomplished on the same day of the second interview on Saturday, the eighth of July 2017, in a different time at 04:42 PM. The researcher began the interview by asking the student $\mathrm{C}$ if she could differentiate some words that have similar a sound when listening to English conversation. She said yes. She also gave the explanation on how she identified it.

"...more focus on the full sentence, which is meant by the speaker.

This word or that second word". (C1) 
Continuing to the second question, the interviewee said that she could recognize the basic grammatical structure of the text that she had heard even sometimes it's unclear.

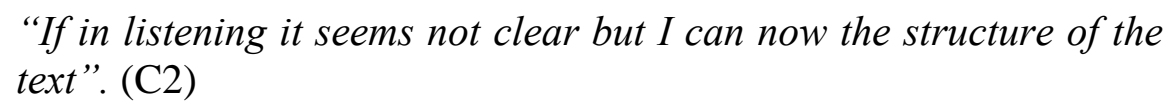

Just like other interviewees, when student $\mathrm{C}$ was asked about the percentage of her understanding on the passage that she often heard, she said she only understand half of it.

"I only understand half of it. I usually just take the main point of the text”. (C3)

Afterward, the interview moved to the fourth question in the inferential level which asked about answering the implied message in the listening task. Again, she answered that she would just take a conclusion to get the answer.

"Even if the answer did not state on the text that I heard, I can make a conclusion from what I have heard". (C4)

Still in the inferential level of the question, at the fifth question, the interviewee was asked if there are any technique used to connecting a passage that she heard and the questions are given. She said nothing special.

"If there are the written questions, I prefer to analyze it first while listening to the passage then match it".

In the sixth question, student $\mathrm{C}$ was confident if she could recognize the use of discourse markers and cohesive devices. Not different as before, about two last questions, she also said that it's hard to understand a message in a conversation or text in English by only listening except the topic is familiar for them.

On Wednesday, $26^{\text {th }}$ of July 2017 at 06:58 PM, the researcher did an interview with student B. Just like the questions asked before, for the first question the interviewee was asked about the ability to differentiate some familiar sound of words and again the interviewee admitted she could do that. She also gave an example of it.

"Yes, I can do that. I also can give the example, the pronunciation of the word "sight" and "site", when we listened to it, it may sound similar but I can differ it." (B1)

Moreover, in the second question, she sometimes could recognize the basic grammatical of the text and sometimes not.

"Unless the text is given to me I can know, but if it there isn't maybe I can't". (B2)

Next, to the third question, student B said that she only understood some words in questions that she heard.

"Not all, but some of them". (B3) 
About answering the implied message in the listening task, the interviewee admitted if she could do it. Besides, while answering the task in listening activity, there wasn't any technique used by student B to choose the correct answer.

"I only listen to the text carefully, so that I can get the answer". (B4)

Furthermore, the fifth and sixth questions were still the same as other students as well as the seventh and eighth questions.

The last interview was taken on Wednesday, in the twenty-sixth of July 2017 at 07:04 PM. Unlike student B, student D admitted sometimes she felt hard in differentiating some words that sound similar when doing a listening activity.

\section{"Sometimes I can, but sometimes I can't" (D1).}

For the second and third questions, student $\mathrm{D}$ answer is not really different as other interviewees. However, in the fourth question, only D student who admitted if she was using note taking as a technique on answering some listening task while doing a listening activity in the campus.

"There's nothing special way in answering, I just listen and then take a note”. (D5)

Recognizing the discourse markers and cohesive devices is not a problem for student D. About the two last questions in the critical level, the interviewee confessed if she could do but sometimes she also ensured she would have a mistake.

"Yes, I can as well as I sure there will be a mistake there". (D7)

\section{Discussion}

In term of listening skill, the university students at least must able to pass three levels of listening skill, they are: literal, inferential, and critical level, to be qualified to have a good quality in listening skill. Based on the students' listening test result, it shows that the dominant level which easily completed by the students of IAIN Samarinda is in literal level. In inferential level, they started to get a little problem and they made some mistakes in the critical level. However, it can be concluded that students have a good skill to answer some questions in different levels.

Further, the students' interview result denotes that in answering all of the interview question sometimes the student has similar ideas, for instance in answering sixth and seventh questions, they thought it still difficult to be able to give an appropriate answer of what they have listened. It is because they think even in their own mother tongue, it hard to think critically, so how they can do that in another language. Nevertheless, they also have a different opinion in some sections.

So far, by looking to the students' answer in the interview, the researcher can get the information that all students have their own technique in facing listening class. For instance, to answer some question, sometimes the students use their prior knowledge to deal with the question that they get in listening task. It proves that students know how listening is processed as stated by Nation \& Newton (2009) that bottom-up 
process of listening involves the listener in going from the whole-their prior knowledge and their content rhetorical schemata - to the parts. So, this enables the students make easy on choosing the right answer for their task.

In the final result of the findings, it is found that the answers of the students can be categorized in a good quality of listening skill. The result, then, was parallel with the previous study conducted by El-Meysarah (2015) that the students of the state university of Surabaya have quite good quality in listening. In opposite, the result of this research finding is different to the result found by Ristanti, et al. (2016) that the second-semester students of English Study Program FKIP-UR were in poor level.

It is the role of English teachers and lecturers to develop the students' ability in listening. Minimizing the anxiety (Hidayati, 2018), maximizing practice and exposure English (Maizatulliza, \& Kiely, 2018), encouraging the students' motivation (Mahammed \& Mohd Rawian, 2018), diversifying the tasks (Darmi, et al., 2016) are some ways, can be implemented, to get the best result in the teaching of listening. Enhancing the learners' self-efficacy and the out-of-class English learning (Yang, 2016; Brown, 2017) and promoting critical thinking (Omar \& Safinas, 2016; Al Zahrani \& Elyas, 2017; Teh, et al., 2018) should be applied to get a higher English language achievement, particularly in listening, for the students. The English teacher might instruct the students do immersion English in daily usage (Du-Babcock, 2016) to make them fluent in English as well as introducing global issues by knowing other cultures (Lirola, 2018) to have a better understanding about English in real life.

\section{Conclusion}

The aim of this inquiry was to know the students' quality of listening skill based on the mastery levels of listening, they are: literal, inferential, and critical. The literal level desires the student have three main types of skills: phonological, syntactic, and lexical skills. The inferential level is related to the skill of text comprehension. Moreover, critical level leads the students enable making an appropriate answer about the message, the speaker's personality and the topic of conversation. The finding shows that the students of English Education Department of IAIN Samarinda are in the inferential level of listening. The result shows that the students are in different level of listening mastery.

\section{References}

Afsharrad, Mohammad \& Nafchi, Asghar Moulavi. (2015). The Effect of Transcribing on Elementary Iranian EFL Learners' Listening Comprehension. Dinamika Ilmu, 15(2), 2015

Al Musalli, Alaa. (2001). Listening Comprehension as a Complex Skill and the SubSkills Involved in the Process of Speech Perception. Retrived from https://www.researchgate.net/publication/39019454_Listening_Comprehensio n_as_a_Complex_Skill_and_the_Sub-

Skills_Involved_in_the_Process_of_Speech_Perception 
Al Zahrani, B. S. \& Elyas, Tariq. (2017). The Implementation of Critical Thinking in a Saudi EFL Context: Challenges and Opportunities. IJELTAL (Indonesian Journal of English Language Teaching and Applied Linguistics), 1(2), 2017.

Barta, Eva. (2010). Test Taker Listening Comprehension Sub-Skills and Strategies, WoPaLP Vol. 4, 2010.

Brown, C. A. (2017). Understanding the Out-of-class English Learning Choices of Students in Taiwan. ASIAN TEFL, 2(1), 2017

Cendra, Anastasia Nelladia. (2017). BBC Radio Drama Series Cabin Pressure: Abu Dhabi for Giving Listening Exposure to Students: A View from Humour Perspective. Indonesian Journal of EFL and Linguistics, 2(2), 2017

Darmi, R., Behak, F.P., and Mohamed, Y. (2016). Diversifying Tasks in the English Language Classroom. ASIAN TEFL, 1(1), 2016 http://dx.doi.org/10.21462/asiantefl.v1i1.2

Du-Babcock, Bertha. (2016). Assessing the Effects of Short-Term Culture and Language Immersion Program: A Hong Kong Case. ASIAN TEFL, 1(2), 2016

El Meysarah, Cintya. (2015). Listening of news through cornell note-taking system in a univeristy critical listening class. RETAIN, 3(1), 2015.

Hanafi, H. (2016). The Effect of Discovery Learning Method Application on Increasing Students' Listening Outcome and Social Attitude. Dinamika Ilmu, 16(2), 2016

Hancock B., et al. (2007). An Introduction to Qualitative Research. The NIHR RDS $\mathrm{EM} / \mathrm{YH}$

Hidayati, Tuti. (2018). Student Language Anxiety in Learning English: Examining non-English Major Students in Rural Area. IJELTAL (Indonesian Journal of English Language Teaching and Applied Linguistics), 2(2), 2018.

Javed, Muhammad. (2013). Analysis Studies' Competency in Listening Comprehension of the English Language at Pakistani Secondary School Level, Middle-East Journal of Scientific Research 16(3), 2013.

Keputusan Direktur Jendral Penndidikan Tinggi Departemen Pendidikan Nasional Republik Indonesia Nomor: 43/DIKTI/Kep/2006.

Khotari, C. R. (2004). Research Methodology: Methods and Techniques, Ed. 2, New Dehli: New Age International Publishers

Lirola, María Martínez. (2018). Introducing Global Issues in A Language Classroom: Knowing Other Cultures by Analysing Multimodal Texts from NGOs. ASIAN TEFL, Vol 3(1), 2018

Mahammed, Azilah \& Mohd Rawian, Rafizah. (2018). English Learning Motivation of First-Year Students in Universiti Sultan Zainal Abidin (UniSZA). ASIAN TEFL, Vol 3(1), 2018

Maizatulliza, M. \& Kiely, R. (2018). An Analysis of Focus on Form Practice in Communicative English Language Teaching Classrooms. IJELTAL (Indonesian Journal of English Language Teaching and Applied Linguistics), 2(2), 2018.

Maxom, Michelle. (2009). Teaching English as a Foreign Language for Dummies. London: John Wiley \& Sons, Ltd 
Miles, Matthew B. \& Huberman, A. Michael. (1994). Qualitative Data Analysis, Ed.2, United State of America: SAGE Publications

Nation, I.S.P. \& Newton, Jonathan. (2009). Teaching ESL/EFL Listening and Speaking. New York: Routledge, Taylor and Francis

Omar, A. \& Safinas M. A.A., Intan. (2016). Thinking Maps to Promote Critical Thinking through the Teaching of Literature in the ESL Context. IJELTAL (Indonesian Journal of English Language Teaching and Applied Linguistics), 1(1), 2016

Reid, Etna R. (1981). Comprehension Skill can be Taught. Salt Lake City: Educational Leadership; Association for Supervision and Curriculum Development

Ristanti, S., et al. (2016). A Study on the Ability in Listening Comprehension on Descriptive Text by the 2nd Semester Students of English Study Program FKIP-UR JOM, 3(1), 2016

Samawiyah, Zuhrotun \& Saifuddin, Muhammad. (2016). Phonetic Symbols through Audiolingual Method to Improve the Students' Listening Skill. Dinamika Ilmu, 16(1), 2016

Teh, N C., et al. (2018). Promoting Higher Order Thinking Skills in Literature Class via Critical Thinking Module (CTM) . ASIAN TEFL, Vol 3(1), 2018

Yang, Pei-Ling. (2016). In-Class Online Discussion Activities to Enhance EFL Learners' English Self-Efficacy and Language Learning Strategies. ASIAN TEFL, 1(2), 2016 